\title{
Sabun Kalsium dari PFAD untuk Pakan Ruminansia: Kualitas PFAD Sebagai Sumber Asam Lemak Bebas
}

Lienda A. Handojo*, Antonius Indarto, Dian Shofinita, Muhammad Reyhan Saadi, Dea Yulistia, Fathinah I. Hasyyati

Program Studi Teknik Kimia, Fakultas Teknologi Industri, Institut Teknologi Bandung, Jalan Ganesha 10, Bandung 40132, Indonesia

*e-mail: lienda@che.itb.ac.id

\begin{abstract}
Abstrak. Dalam rangka meningkatkan komoditas susu di Indonesia, pemerintah menargetkan sapi perah lokal harus mampu menyuplai $41 \%$ produksi susu dalam negeri pada 2022. Salah satu cara untuk menaikkan produksi susu sapi adalah memberikan suplemen pakan berupa sabun kalsium. Sabun kalsium telah banyak digunakan di luar negeri, namun tidak di Indonesia, untuk menaikkan produksi susu sekaligus fertilitas ruminansia. Sabun kalsium dapat dibuat melalui reaksi fusi termodifikasi antara Palm Fatty Acid Distillate (PFAD) sebagai sumber asam lemak bebas dengan sumber kalsium. Penelitian ini mengevaluasi pengaruh jenis PFAD terhadap kualitas produk sabun kalsium. PFAD yang digunakan berasal dari beberapa industri pengolahan kelapa sawit di Indonesia, yaitu Kabupaten Sidoarjo, Kabupaten Bekasi, Kota Bekasi, dan Kabupaten Pelalawan dengan rentang angka asam 195 - $221 \mathrm{mg} \mathrm{KOH/g} \mathrm{sampel.}$ Produk sabun kalsium yang dihasilkan kemudian dianalisis nilai angka asam untuk menguantifikasi kualitasnya. Keempat produk sabun kalsium secara keseluruhan memiliki angka asam di bawah $1 \mathrm{mg} \mathrm{KOH/g} \mathrm{sampel.} \mathrm{Rendahnya}$ angka asam pada produk membuktikan bahwa keempat sumber PFAD dapat digunakan sebagai bahan baku pembuatan sabun kalsium dengan kualitas baik.
\end{abstract}

Kata kunci: angka asam, kalsium oksida, PFAD, pakan ruminansia, sabun kalsium.

Abstract. Calcium Soap from PFAD for Ruminant Feed: Quality of PFAD as a Source of Free Fatty Acids. In order to increase the milk commodity in Indonesia, the government targets local dairy cattle to be able to supply $41 \%$ of domestic milk production by 2022. One way to increase the production of cow's milk is to provide a dietary supplement in the form of calcium soap. Calcium soap has been widely used overseas, but not in Indonesia, to increase milk production as well as ruminant fertility. Calcium soaps can be made by modified fusion reactions between PFAD as a source of free fatty acids with a calcium source. This study evaluated the effect of PFAD type on the quality of calcium soap products. PFAD used were obtained from several palm oil processing industries in Indonesia, namely Sidoarjo regency, Bekasi regency, Bekasi city, and Pelalawan regency with the acid number $195-221 \mathrm{mg} \mathrm{KOH} / \mathrm{g}$ sample. The resulting calcium soap product is then analyzed for the acid number to quantify its quality. The four calcium soap products had an acid number below $1 \mathrm{mg} \mathrm{KOH} / \mathrm{g}$ sample. The low acid number in the product indicates that the four sources of PFAD can be used as raw material for producing calcium soap with good quality.

Keywords: acid value, calcium oxide, calcium soap, PFAD, ruminant feed.

Graphical Abstract

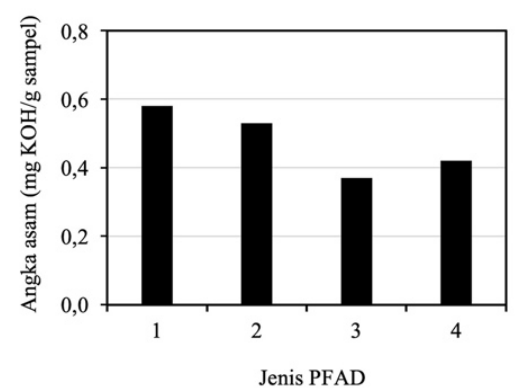

\section{Pendahuluan}

Konsumsi susu di Indonesia masih termasuk yang terendah di Asia Tenggara. Konsumsi susu termasuk produk olahan yang mengandung susu di Indonesia hanya berkisar 11,8 liter/kapita/tahun dibandingkan Malaysia 36,2; Myanmar 26,7; Thailand 22,2; dan Filipina 17,8 liter/kapita/tahun (Kementan RI, 2017). Susu sapi dalam negeri pun hanya mampu memasok
$26,2 \%$ dari ketersediaan susu di Indonesia sementara $73,8 \%$ diperoleh dari impor.

Kondisi komoditas susu di Indonesia tersebut cukup memprihatinkan. Oleh karena itu, pemerintah menargetkan sapi perah lokal harus mampu menyuplai $41 \%$ produksi susu dalam negeri pada 2022 (Kemenperin RI, 2018). Salah satu cara untuk menaikkan produksi susu sapi tersebut adalah memberikan pakan yang dapat 
memenuhi tingginya kebutuhan energi pada masa laktasi, idealnya berupa lemak. Namun, pemberian lemak secara langsung dapat membentuk lapisan minyak yang dapat membunuh bakteri rumen serta mengurangi kecernaan serat (Volac Wilmar, 2016).

Lemak dapat direaksikan dengan sumber kalsium melalui reaksi fusi termodifikasi untuk menghasilkan sabun kalsium (Szczepanek dkk., 1970; Handojo dkk., 2019a; Indarto dkk., 2020). Penelitian terdahulu membuktikan bahwa kalsium oksida dapat menghasilkan sabun kalsium lebih baik dibanding kalsium hidroksida (Handojo dkk., 2018). Sabun kalsium yang merupakan lemak terproteksi dapat melewati rumen secara utuh, tanpa mempengaruhi bakteri rumen atau kecernaan serat, lalu dicerna di abomasum (Volac Wilmar, 2016). Sabun kalsium merupakan suplemen pada pakan ruminansia yang telah dikenal di luar negeri namun jarang digunakan di Indonesia. Pemberian sabun kalsium telah terbukti mampu menaikkan produksi susu sekaligus fertilitas ruminansia.

Lemak sebagai salah satu bahan baku pembuatan sabun kalsium dapat diperoleh dari Palm Fatty Acid Distillate (PFAD). PFAD merupakan hasil samping dari distilasi minyak sawit mentah yang kaya akan asam lemak bebas yaitu sebesar 81,70\% (Pitoyo, 1991). Perbedaan proses pengolahan di tiap industri pengolahan kelapa sawit menghasilkan PFAD dengan kadar komponen yang berbeda-beda dan hingga saat ini belum ada pembahasan atau penelitian terkait pengaruh kualitas PFAD terhadap produk sabun kalsium. Penelitian ini bertujuan untuk mengevaluasi pengaruh sumber bahan baku PFAD dari beberapa industri pengolahan kelapa sawit di Indonesia terhadap kualitas produk sabun kalsium. Selain itu, penggunaan PFAD dari berbagai sumber dengan perbedaan kandungan asam dapat digunakan untuk menguji prosedur produksi yang menghasilkan produk yang tetap memiliki spesifikasi baik. Angka asam produk dipilih sebagai parameter kualitatif yang digunakan sebagai basis evaluasi reaksi karena dapat mengindikasikan jumlah asam lemak bebas yang terkonversi menjadi produk.

\section{Metodologi}

Penelitian ini menggunakan PFAD sebagai sumber asam lemak bebas dan $\mathrm{CaO}$ teknis sebagai sumber kalsium. PFAD diperoleh tanpa pengolahan lebih lanjut dari beberapa industri pengolahan kelapa sawit di Indonesia, yaitu Kabupaten Sidoarjo (PFAD 1), Kabupaten Bekasi (PFAD 2), Kota Bekasi (PFAD 3), dan Kabupaten Pelalawan (PFAD 4). Sementara itu, $\mathrm{CaO}$ diperoleh dari penambangan batu kapur di Padalarang yang diproses lebih lanjut untuk mendapatkan bubuk $\mathrm{CaO}$ pada kehalusan tertentu ( $<100$ mesh).

Sabun kalsium pada penelitian ini dibuat melalui reaksi fusi termodifikasi (lihat metode reaksi pada Handojo dkk., 2019). Sejumlah PFAD dipanaskan hingga sempurna meleleh kemudian dicampurkan bubuk $\mathrm{CaO}$ pada rasio mol $\mathrm{CaO} / \mathrm{PFAD}$ tertentu (antara 1 hingga 1,4). Sesaat setelah campuran homogen, air panas ditambahkan dan reaksi dilangsungkan hingga tercapainya temperatur puncak pada campuran produk
(90-100 $\left.{ }^{\circ} \mathrm{C}\right)$. Pengaruh rasio mol $\mathrm{CaO} / \mathrm{PFAD}$ dan temperatur puncak telah diteliti sebelumnya (Handojo dkk., 2019b).

Analisis angka asam kemudian dilakukan pada semua umpan dan produk sesuai metode standar ISO 660:1990. 1 gram sampel sabun kalsium dilarutkan dalam etanol pada temperatur $60^{\circ} \mathrm{C}$ selama 10 menit. Setelah itu, larutan ditambahkan indikator fenolftalein dan dititrasi menggunakan kalium hidroksida $0,01 \mathrm{~N}$ hingga terbentuk warna merah muda. Massa kalium hidroksida dalam miligram yang digunakan untuk menetralkan 1 gram sampel disebut sebagai angka asam.

\section{Hasil dan Pembahasan}

Empat sumber PFAD berbeda digunakan pada penelitian ini. Berdasarkan analisis angka asam, rata-rata kandungan asam lemak bebas pada PFAD ditampilkan pada Tabel 1.

Kadar asam lemak bebas yang berbeda salah satunya dapat dipengaruhi oleh bahan baku serta kondisi vakum saat proses deodorisasi. Kondisi vakum inilah yang dapat mengangkat uap asam lemak bebas hingga kemudian disebut sebagai PFAD (Silalahi dkk., 2017). Kondisi vakum bertujuan untuk menghilangkan gas oksigen yang masih terikut sehingga asam lemak bebas menguap untuk kemudian dikondensasikan dengan asam lemak bebas yang didinginkan sehingga dihasilkan PFAD (Pahan, 2008).

Produk sabun kalsium dari keempat jenis PFAD dianalisis terhadap angka asam. Angka asam rendah lebih disukai karena mengindikasi konversi reaksi tinggi serta mengurangi kandungan asam lemak di bahan. Hal ini penting karena reaktan yang tidak bereaksi dapat membuat campuran produk tidak stabil dan apabila campuran berkontak dengan air, campuran tersebut akan menjadi mudah tengik selama penyimpanan. Selain itu, produk dengan angka asam rendah tidak akan mengganggu pencernaan ruminansia khususnya di bagian rumen.

Reaksi kimia yang terjadi pada konversi asam lemak menjadi sabun kalsium menggunakan metode fusi termodifikasi adalah:

$\mathrm{CaO}+2 \mathrm{RCOOH} \rightarrow \mathrm{Ca}(\mathrm{OOCR})_{2}+\mathrm{H}_{2} \mathrm{O}$

Reaksi di atas bersifat eksotermis ditandai dengan kenaikan temperatur reaksi hingga bisa mencapai $100^{\circ} \mathrm{C}$. Tingginya nilai temperatur puncak dapat mengindikasikan bahwa sebagian besar atau seluruh asam lemak telah bereaksi atau terkonversi.

Tabel 1. Angka asam pada PFAD

\begin{tabular}{cc}
\hline Jenis PFAD & $\begin{array}{c}\text { Angka Asam } \\
\text { (mg KOH/g sampel) }\end{array}$ \\
\hline PFAD 1 & 221,7 \\
PFAD 2 & 202,1 \\
PFAD 3 & 217,2 \\
PFAD 4 & 195,0 \\
\hline
\end{tabular}




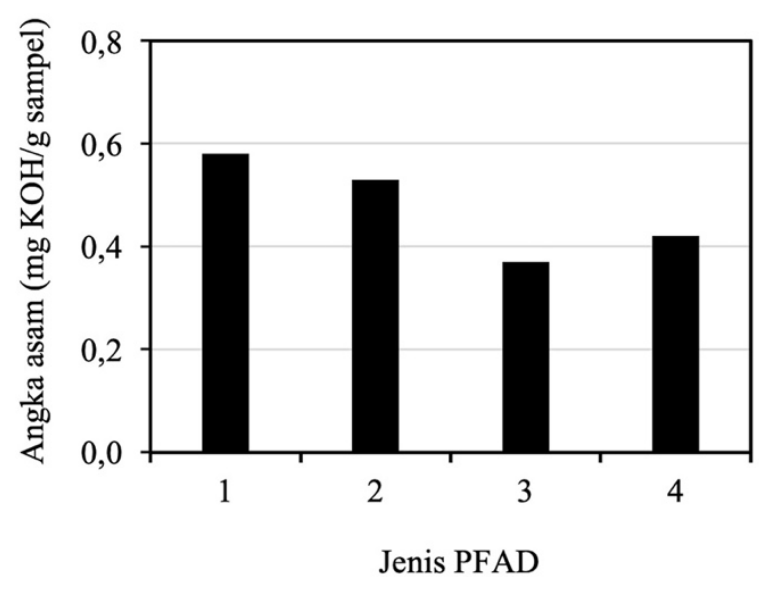

Gambar 1. Angka asam pada sabun kalsium dari beberapa jenis PFAD

Gambar 1 menunjukkan hasil analisis angka asam pada keempat sabun kalsium. Sabun kalsium dengan PFAD 1 memiliki angka asam sebesar 0,58; sementara PFAD 2 sebesar 0,53; PFAD 3 sebesar 0,37; dan PFAD 4 sebesar $0,42 \mathrm{mg} \mathrm{KOH} / \mathrm{g}$ sampel. Secara keseluruhan, produk sabun kalsium telah memiliki angka asam di bawah $1 \mathrm{mg} \mathrm{KOH} / \mathrm{g}$ sampel.

Rendahnya angka asam pada keempat produk mengindikasikan produk telah mencapai kualitas yang baik. Nilai konversi asam lemak menjadi sabun kalsium mencapai 99,7 - 99,9\%. Hal ini membuktikan pembuatan sabun kalsium yang dilakukan baik proses produksi, kondisi operasi, dan bahan baku dapat memenuhi syarat yang telah ditentukan. Keempat jenis PFAD sebagai sumber asam lemak bebas dengan rentang angka asam 195,0 - 221,7 mg KOH/g sampel dapat digunakan sebagai bahan baku pembuatan sabun kalsium untuk pakan ruminansia dengan angka asam rendah.

\section{Kesimpulan}

PFAD yang diperoleh dari berbagai sumber di Indonesia memiliki angka asam yang berbeda-beda yaitu pada rentang 153,06-217,18 $\mathrm{mg} \mathrm{KOH} / \mathrm{g}$ sampel. Penggunaan keempat PFAD tersebut sebagai sumber asam lemak bebas pada pembuatan sabun kalsium dapat menghasilkan produk dengan kualitas baik. Secara keseluruhan, semua produk memiliki angka asam di bawah $1 \mathrm{mg} \mathrm{KOH} / \mathrm{g}$ sampel.

\section{Ucapan Terima Kasih}

Tim penulis mengucapkan terima kasih kepada BPDPKS Indonesia yang telah memberikan bantuan dana penelitian.

\section{Daftar Pustaka}

Handojo, L.A.; Indarto, A.; Shofinita, D.; Meitha, A.; Nabila, R.; Triharyogi, H.; Hakim M.G.A.; Saadi M.R., Calcium Soap from Palm Fatty Acid Distillate for
Ruminant Feed: $\mathrm{Ca}(\mathrm{OH})_{2}$ As Calcium Source. MATEC Web of Conferences, 2018, 159, 02062.

Handojo, L.A.; Indarto, A.; Shofinita, D.; Meitha, A.; Nabila, R.; Triharyogi, H., Calcium Soap from Palm Fatty Acid Distillate for Ruminant Feed: Reaction Method. International Journal of Engineering and Advanced Technology, 2019a, 8, 422-425.

Handojo, L.A.; Indarto, A.; Shofinita, D.; Saadi M.R.; Yulistia, D.; Hasyyati, F.I., Calcium Soap from Palm Fatty Acid Distillate for Ruminant Feed: The Influence of Initial Mixing Temperature. IOP Conference Series: Materials Science and Engineering, 2019b, 543, 012017.

Indarto, A.; Handojo, L.A.; Shofinita, D.; Saadi M.R.; Yulistia, D.; Hasyyati, F.I., In-vivo Test of Calcium Soap from Palm Fatty Acid Distillate (PFAD) in Three Cow Farms. IOP Conference Series: Materials Science and Engineering, 2020, 742, 012030.

Pusat Data dan Sistem Informasi Pertanian Sekretariat Jenderal, Kementerian Pertanian, Outlook Susu. Jakarta: Pusat Data dan Sistem Informasi Pertanian Sekretariat Jenderal Kementerian Pertanian, 2017.

Kemenperin RI, Suplai Susu Segar Domestik akan Naik 41\%, https://kemenperin.go.id/artikel/18911/Suplai-

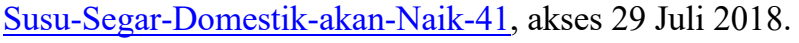

Pahan, I., Panduan Lengkap Kelapa Sawit. Jakarta: Penebar Swadaya, 2008.

Pitoyo, Pemisahan Tokoferol dari Distilat Asam Lemak Minyak Sawit. Tesis Magister, Universitas Gadjah Mada, Yogyakarta, 1991.

Silalahi, R.L.R.; Sari, D.P.; Dewi, I.A., Pengujian Free Fatty Acid (FFA) dan Colour untuk Mengendalikan Mutu Minyak Goreng Produksi PT. XYZ. Industria: Jurnal Teknologi dan Manajemen Agroindustri, 2017, 6(1), 41-50.

Szczepanek, A.; Gunter, K., Process for Preparing Metal Soap Mixtures. U.S. Patent No. 3,519,571, 1970.

Volac Wilmar, Megalac Product Sheets. Royston: Volac International Limited, 2016. 